Test-ban seismology

\section{Soviet visit to US cut short}

Washington

THE unique private effort to monitor nuclear testing in the United States and the Soviet Union is off and running, with three seismic monitoring stations now established near the Soviet test facility in Semipalatinsk. But phase two, due to start next week with the arrival of five Soviet seismologists for site selection in this country, will proceed as planned. The US State Department has limited the Soviet delegation's stay to one week, and has refused to permit a planned visit to potential monitoring sites.

The monitoring effort comes from an agreement signed last spring by the Natural Resources Defense Council (NRDC), a private non-profit organization, and the Soviet Academy of Sciences (see Nature 321, 638; 1986). Phase one of the agreement was completed this summer when NRDC scientists established seismic monitoring stations at Karkaralinsk, Bayanaul and Karasu near Semipalatinsk.

Preliminary measurements have been taken at each site, and construction is nearly completed on $300-\mathrm{ft}$ boreholes for high-frequency seismometers. Returning last week from a visit to the Soviet sites, NRDC senior scientist Thomas Cochran declared the Soviets had done "an exceptional job, spending some $\$ 150,000$ for construction of each station".

The US government, by contrast, has not welcomed the NRDC effort. The administration feels that arms control issues should be carried out on a government-to-government basis, not by private organizations. The goal of the NRDC/Soviet Academy effort is "to get the verification issue out the way", says Cochran. But the State Department believes that there is a better way to monitor nuclear testing. The government's approach is a a hydrodynamic yield measurement technique called CORRTEX, for Continuous Reflectometry for Radius versus Time Experiment.

A coaxial cable is placed in a hole parallel to the nuclear device. After the explosion, the rate of change in the cable length is used to estimate the yield of the device. President Reagan last March offered to demonstrate CORRTEX for Soviet scientists, but so far that offer has not been accepted. The State Department made viewing a CORRTEX demonstration a condition for granting the two-week visa sought by the Soviet seismologists, but Cochran says that Soviet officials decided that the seismologists would be "inappropriate" for determining the value of the system.

During their visit, the Soviet delegation will also visit Teledyne Geotech and Refraction Technology in Dallas, manufac- turers of monitoring equipment for the monitoring effort. NRDC expects to take delivery of the new equipment later this month, and after testing it should be installed on site in the Soviet Union by early next year. The Soviet seismologists will also discuss with seismologists at the Scripps Institution at the University of California, San Diego, the selection of monitoring sites near the US Nevada test facility. Three potential sites have been identified at Nelson and Railroad Valley, both in Nevada, and Deep Springs, California.

Joseph Palca

\section{British seek funds}

The British team, invited by the Soviets to join the Americans in monitoring nuclear tests at Semipalatinsk, is attempting quickly to raise the bulk of the $£ 200,000$ it will need for the coming year.

Two committees will steer the project, one composed of eminent scientists with a reputation for raising money and the other of seismologists. Seismologists from the Universities of Leeds, Liverpool and Leicester have already offered to help.

The invitation was extended by the Soviet Academy early last month to two British scientists visiting Moscow, Dr Frank Barnaby, former director of the Stockholm International Peace Research Institute, and Dr Jeremy Leggatt, lecturer in Earth sciences at Imperial College in London.

Apart from Barnaby and Leggatt, the project team includes Dr David Davies, a seismologist and former editor of Nature who is now director of the Dartington North Devon Trust, Professor Martin Rees of the Institute of Astronomy, Cambridge, and Joseph Rotblat, emeritus professor of physics at St Bartholomew's Hospital Medical School in London.

The British team should be in place by mid-December, before the test-ban treaty lapses at the end of the year. If the group can attract sufficient funds, two monitoring positions will be created, manned by two people at any one time.

Because of the political aspects of the project, no research council support will be available, Leggatt says, in spite of the scientific value of the proposed collaboration between British and Soviet seismologists. It is hoped, however, that Quaker and US foundations will provide support.

The equipment will all be supplied from the West, although the Soviets will have access to data retrieved. The British monitoring positions will collect data on the crustal struture below the test sites, particularly seismic wave propagation.

Bill Johnstone
Strategic Defense Initiative Academicians
doubt efficacy

Washington

SCIENTISTS at Cornell University announced last week the results of a commissioned survey on views held by members of the National Academy of Sciences about the Strategic Defense Initiative (SDI). The principal conclusion is that 78 per cent of those responding believed that the prospects were "poor" or "extremely poor" that SDI can be made "survivable and cost effective at the margin" within the next 25 years, while only 4 per cent believed the chances of success were better than even. Ninety-eight per cent believed SDI could not provide an effective defence of the US population within 25 years in the face of Soviet attempts to thwart it, and 94 per cent believed that goal to be impossible even if the Soviets froze their arsenals at current levels.

The survey has caused some discomfort at the academy because it does not represent an official view; although the Cornell scientists have been careful to make the distinction clear, academy staff feel it is now perceived as opposed to SDI. The study, designed and conducted by the Cornell Institute for Social and Economic Research, was instigated by Peter Stein, a physics professor at Cornell, and paid for by the Ploughshares Fund of San Francisco and the MacArthur Foundation. The survey was sent to all 663 academy members in the physical, mathematical and engineering sciences, and responses were received from 71 per cent.

The study nevertheless received some influential support from academy members. A covering letter sent out with the questionnaire, signed by well-known Cornell members, urged recipients to give a few minutes to respond, saying that a "definitive poll" could provide a "useful contribution to one of the most vital science policy issues of our time".

The administration, well used to academics querying SDI, is unlikely to be immediately influenced by the survey. But Congress is another matter: it recently voted $\$ 3,500$ million for SDI research in fiscal year $1987, \$ 1,900$ million less than the administration requested. But for a one-vote close call, the figure would have been only $\$ 3,300$ million, and doubts about SDI's feasibility played a significant part in reducing the budget. Senator William Proxmire (Democrat, Wisconsin), a prominent SDI critic who was invited to the press conference at which the survey was announced, said "the best scientific minds of the country are telling [the President] loud and clear that Star Wars won't work and that it's a waste of money".

Tim Beardsley 